\title{
Biblia i polemiki. Rozmowa Alicji Bielak z Jakubem Korylem oraz Maciejem Ptaszyńskim
}

\author{
Alicja Bielak \\ Uniwersytet Warszawski \\ alicjabielak@gmail.com (D) https://orcid.org/0000-0003-0701-0634 \\ Jakub Koryl \\ Uniwersytet Jagielloński \\ jakub.koryl@uj.edu.pl (D) https://orcid.org/0000-0002-7233-7740 \\ Maciej Ptaszyński \\ Uniwersytet Warszawski \\ m.ptaszynski@uw.edu.pl (D) https://orcid.org/0000-0003-2508-061X
}

Alicja Bielak: Wiek szesnasty to czas sporów wokół problemu tożsamości filologii i biblistyki jako dyscyplin. W jaki sposób doszło do ich rozróżnienia?

Jakub Koryl: Były to problemy szalenie osobliwe, w wielu miejscach nieoczywiste i naznaczone zadziwiającymi zwrotami, na które jeszcze zwrócę uwagę. Wszelkie próby opisu tego, jak kształtowała się tożsamość dyscypliny, którą dzisiaj moglibyśmy nazwać filologią klasyczną albo filologią grecką, wymagają dużej ostrożności i skrupulatności pojęciowej. Unikałbym tutaj jednoznacznych odpowiedzi, a w każdym razie takich, które sugerują jednoznaczne rozwiązania. Historyczny rodowód prób samoutwierdzenia się tych dyscyplin jest dawny, w pewnym sensie również zupełnie oczywisty, bo postacią, na którą główni uczestnicy wczesnonowożytnego sporu o filologię i biblistykę się stale powoływali, był oczywiście św. Hieronim jako tłumacz i komentator Pisma Świętego. 
Hieronim jako pierwszy tak stanowczo postawił pytanie o kompetencje tłumacza, o hermeneutyczną specyfikę tekstu biblijnego, nie tekstu w wersji greckiej czy hebrajskiej, tylko przekładu, w tym konkretnym przypadku - przekładu łacińskiego. Hieronim często wracał do tego problemu, bo i w kontekście kontrowersji z Rufinem z Akwilei na temat Orygenesa, w swoich dyskusjach na temat dziewictwa i małżeństwa, wreszcie w uwagach na temat Septuaginty. Hieronim rozróżnia dwa porządki. Z jednej strony mówi o kompetencjach kogoś, kogo po łacinie nazywa interpres, czyli tłumaczem, komentatorem, i kompetencji kogoś, kogo nazywa vates, czyli prorokiem. I powiada, iż tym się oni między sobą różnią, że interpres polega wyłącznie na określonej, a dla siebie dystynktywnej wiedzy fachowej. Hieronim wskazuje tu na dwa obszary takiej wiedzy. Z jednej strony mówi on o eruditio, bliskiej cycerońsko-krasomówczemu wykształceniu ogólnemu, a z drugiej strony o verborum copia, czyli retorycznej biegłości nie tylko w zakresie bogactwa leksykalnego języka, ale nade wszystko jego społecznego rodowodu i takiej samej sprawczości, które w retoryce rzymskiej określano jako consuetudo albo genus et vis verborum. To filologiczny i zawodowy, by tak rzec, ekwipunek komentatora-tłumacza. Natomiast vates podlega działaniu Ducha Świętego, jest wyjęty spod działania zasad gramatycznych i filologii, przepowiada to, co przyszłe, nie komentuje zaś tego, co zostało napisane.

Kiedy św. Hieronim zastanawia się nad wartością hermeneutyczną Septuaginty, komentuje słynny list Pseudo-Arysteasza, list, z którego znamy tę nieprawdopodobną historię o siedemdziesięciu tłumaczach, którzy pracując osobno, przetłumaczyli na język grecki Stary Testament w dokładnie taki sam sposób. Hieronim zwraca uwagę na pewien szczegół - można by rzec - ciekawostkę dla skrupulatnych filologów i bynajmniej nie robi tego mimochodem. Wyjaśniając specyfikę pracy siedemdziesięciu tłumaczy, którzy według przekazu listu Pseudo-Arysteasza mieli działać właśnie z natchnienia Ducha Świętego, Hieronim powiada, że ich praca polegała jednak na czymś zupełnie innym, i posługuje się dwoma czasownikami na oznaczenie dwóch różnych czynności: pisać i przepowiadać - scribere i profetare. Wedle jego oceny tłumacze Septuaginty nie tyle przepowiadali sposobem proroków, 
ale pisali metodą komentatora-tłumacza. Erazm z Rotterdamu, który uznawał św. Hieronima za swojego patrona, nie tylko szybko poznał się na jego diagnozie, że kim innym jest tłumacz, a kim innym prorok, ale także przyjął ją jako własną, uznał za czynnik kształtujący jego tożsamość intelektualną.

Zapewne już pod koniec lat osiemdziesiątych XV wieku Erazm natrafił na informacje o tym, że podziwiany przezeń Lorenzo Valla kilkadziesiąt lat wcześniej opracował filologiczny komentarz do Nowego Testamentu. Na wyobraźnię młodego Erazma takie odkrycie działało wyjątkowo mocno. Nie znał on bowiem ani samego komentarza, ani nawet miejsca, gdzie mógłby się z nim zapoznać. Udało mu się to w roku 1504 w klasztorze remonstrantów w Park, wtedy to były przedmieścia Lowanium, dzisiaj część tego miasta. Rok później wydał Annotationes in Novum Testamentum Valli i poprzedził tę edycję swoją przedmową ${ }^{1}$. Przytoczę jej fragment, dosyć długi wprawdzie, ale bardzo treściwy. Dla kształtowania się humanistycznej filologii biblijnej to dokument, który trudno dzisiaj przecenić. Erazm powiada tak:

Przewiduję, że znajdą się jacyś, którzy ledwie przeczytawszy tytuł dzieła - mowa oczywiście o Annotationes Valli - a przed zapoznaniem się z jego treścią, natychmiast zaczną wykrzykiwać w typowym dla tragedii tonie: „wielkie nieba!”, mimo że Arystofanes w Plutosie trafnie radził: „nie złość się i nie krzycz zanim się nie dowiesz”. Jestem także skłonny sądzić, że spośród wszystkich osób w najbardziej odrażający sposób ci będą szkodzić [temu dziełu], dla których jest ono najbardziej pożyteczne, czyli oczywiście teolodzy. To niedopuszczalna lekkomyślność, powiedzą, by człowieka gramatycznego, który wcześniej rozstroił każdą dziedzinę wiedzy, dopuścić z jego zuchwałym piórem do samego Pisma Świętego. Wszelako jeśli dajemy posłuch Mikołajowi z Lyry - który choć nie powiem - nie jest nieukiem, ale z pewnością jest autorem nowszym, który Hieronima nazywa zdziecinniałym starcem i podważa sprawy uświęcone wielowiekową tradycją, który korzysta ponadto z ksiąg żydowskich (skąd przyznajemy, że pochodzi nasze wydanie [to jest Wulgata], jakkolwiek podejrzewam że są one rozmyślnie zniekształcone), to wobec tego na czym polega nikczemność Wawrzyńca [Valli], który porównawszy ze sobą

1 In latinam Novi Testamenti interpretationem [...] adnotationes, J. Bade, Paris 1505. Wszystkie przypisy pochodzą od redakcji. 
kilka starszych i poprawnych kodeksów greckich dał komentarz do Nowego Testamentu? To z tych właśnie źródeł pochodzi bez wątpienia cały Nowy Testament; źródeł, które albo różnią się między sobą, albo z powodu drzemki tłumacza sprawiają wrażenie niezbyt dobrze przełożonych, albo tych, które wyrażone są w bardziej zrozumiały sposób po grecku. Wreszcie Valla dał komentarz do tego, co jest wyraźnie zepsute w naszych tekstach. Czyż nie będą twierdzić, że jako gramatyk Valla nie ma tych samych praw co teolog Mikołaj z Lyry? Nie mówiąc już o tym, że Wawrzyniec przez wielkie umysły uznawany jest zarówno za filozofa jak i teologa. Czy Mikołaj z Lyry, roztrząsając język wypowiedzi, spełnia wówczas obowiązki teologa, czy może raczej gramatyka? Rzecz oczywista, wszelkie interpretowanie należy bowiem do obowiązków gramatyka. Nie ma nic niestosownego w tym, że na pewnych sprawach Jetro zna się lepiej od Mojżesza.

Nie uważam, by godności samej teologii, jako królowej wszystkich nauk, uwłaczało towarzystwo oraz pomoc z szacunkiem jej okazana przez służącą gramatykę. Pomimo że gramatyka zajmuje, zdaniem wielu, niższe miejsce, ale z pewnością żadna pomoc nie jest bardziej konieczna od tej, którą ona daje. Dotyczy ona drobnych spraw, lecz bez nich nikt nie dojdzie do najważniejszych. Zajmuje się błahostkami, lecz te prowadzą ku poważnym kwestiom. Jeśli odpowiedzą, że teologia jest zbyt wielka by ograniczać się prawami gramatyki a wszelka praca nad przekładem [interpretandi negocium], w całości zależy od Ducha Świętego, to zaiste nowy to zaszczyt dla teologów, skoro im tylko godzi się wysławiać w gramatycznie niewłaściwy sposób. Niech wyjaśnią jednak, co miał na myśli Hieronim, pisząc do przyjaciela Dezyderiusza - i tu Erazm cytuje przywoływaną wcześniej przeze mnie obserwację - „czym innym, powiada, jest bycie prorokiem, a czym innym tłumaczem. Tam duch przepowiada sprawy przyszłe, tutaj wykształcenie i zasób słownictwa przekłada to, co rozumie”. Ponadto jaki miałaby sens wskazówka samego Hieronima na temat właściwej metody przekładu Pisma Świętego, gdyby taka zdolność wynikała wyłącznie z Boskiego natchnienia? Ostatecznie z jakiego powodu twierdzi się, że Paweł był wymowniejszy w języku hebrajskim niż w grece? [...] Wszelako, powiadają oni, nie godzi się niczego zmieniać w Piśmie Świętym, gdyż tam nawet kropeczki nad literami nie są wolne od tajemnicy. Przeciwnie, o tyle więcej nie godzi się niszczyć Pisma i tym bardziej to, co przez brak wiedzy zostało zafałszowane, musi zostać pieczołowicie poprawione przez uczonych. Z taką jednak ostrożnością i umiarem, jakiej wymaga każda książka, a Pismo Święte w szczególności. [...] Brakuje rozsądku i przyzwoitości tym, którzy ośmielają się pisać nie tylko na temat Pisma Świętego, ale w ogóle o wszystkich dawnych książkach, jeśli nie znają w pewnym stopniu literatury greckiej i łacińskiej. Gdy tacy ludzie bardzo starają się popisać swoją wielką uczonością, to stają się największym 
pośmiewiskiem dla znawców języków, a cały ów raban milknie, gdy wypowiedziane zostaje greckie słowo ${ }^{2}$.

Dla Hieronima, a nade wszystko dla Valli i Erazma priorytetowym wyzwaniem było przemyślenie hermeneutycznej ontologii przekładu. Celem tej wymagającej, bo na taką skalę bezprecedensowej próby, stało się zeświecczenie wszelkiego przekładu biblijnego, czyli uczynienie zeń tekstu, który podlega takim samym procedurom weryfikacji i falsyfikacji filologicznej, historycznej, krytycznej, którym podlegają inne teksty. Valla przez wiele lat intensywnie polemizował z innym wielkim humanistą Poggio Bracciolinim. Wprawdzie ich dyskusja nie dotyczyła Hieronima czy filologicznych standardów w pracy nad przekładem biblijnym, a autorytetu Cycerona dla kulturowej tożsamości ruchu humanistycznego, ale to właśnie w jej trakcie Valla wyjaśniał, jaki był właściwy cel pracy wykonanej w Annotationes in Novum Testamentum. Przytoczę drugi cytat, znacznie krótszy od poprzedniego, ale równie ważny. Valla powiada tak:

Jeśli coś poprawiam, to nie poprawiam Pisma Świętego, lecz jego przekład, [interpretatio]. Nie jestem przy tym ani zuchwały, co raczej pobożny, ani nie robię nic innego jak tylko lepiej przekładam od wcześniejszego tłumacza. To jest mój przekład, który w odróżnieniu od tamtego - mowa oczywiście o Wulgacie - nazwać należy, jeśli byłoby to w ogóle możliwe, Pismem Świętym. Wszelako we właściwym znaczeniu Pismem Świętym jest to tylko, co zostało napisane przez samych świętych w języku hebrajskim albo greckim. Takim nie jest natomiast tekst łaciński³.

Tutaj w zasadzie interesująca nas diagnoza zostaje postawiona expresis verbis. Przekład biblijny zostaje sprowadzony do poziomu tekstu, na którym zaczyna on podlegać dokładnie tym samym procedurom filologicznym, co każdy inny tekst, traci swój nadprzyrodzony rodowód

2 Cytat za: Opus epistolarum Des. Erasmi Roterodami, denuo recognitum et auctum per P. S. Allen, t. 1, Oxonii 1906. List 182, wiersze 108-146, 158-162, 193-198. Przekł. J. Koryl.

3 Laurentii Vallae patriti Romani atque de lingua Latina bene meriti, Antidoti in Pogium, ad Nicolaum Quintum Pontificem Max. Lib. I, [w:] L. Valla, Opera omnia, t. 1, Torino 1962, s. 268. Przekł. J. Koryl. 
i staje się obszarem działania filologii, eruditio i verborum copia, jak kilkanaście lat później za św. Hieronimem powie Erazm. Jak można sądzić po reakcjach, które wywołała praca Erazma, była to próba wyjątkowo obrazoburcza i destabilizująca zarówno dla tradycji chrześcijańskiej, jak i ówczesnego podziału kompetencji akademickich. Już Maarten van Dorp z uniwersytetu z Lowanium zarzucił mu, że przedkładając oryginał grecki nad Wulgatę, a Wulgatę traktując wyłącznie jako tekst, zmysł krytyczny Erazma narusza tradycyjną, akademicką tożsamość teologii oraz podważa podstawy zachodniego chrześcijaństwa ${ }^{4}$.

Rozróżnienie na vates i interpretes, które Erazm zaczerpnął od św. Hieronima, stało się jednym z epokowych wyzwań dla teologów w pierwszej połowie XVI wieku. Piotr Sutor, adwersarz Erazma z paryskiej Sorbony, obok uniwersytetu w Lowanium, najważniejszego wówczas akademickiego bastionu tradycyjnego chrześcijaństwa, w opublikowanym w 1525 roku traktacie polemicznym De tralatione Bibliae, czyli $O$ tłumaczeniu Biblii, dwa razy rozpatruje Hieronimowe rozróżnienie. Problem jest nad wyraz poważny - to nie obserwacja Erazma czy Valli, że kim innym jest prorok, a kim innym jest tłumacz. To diagnoza postawiona przez doktora Kościoła. Trzeba ją zatem odpowiednio zinterpretować, nie zaś odrzucić.

Sutor objaśnia ją w bardzo osobliwy sposób. W pierwszym miejscu kładzie na karb młodzieńczej zapalczywości, że Hieronim rzuca tę diagnozę mimochodem i nigdy więcej ani do niej powraca, ani jej nie respektuje. To oczywisty nonsens, skoro pojawia się ona u Hieronima w różnych tekstach pisanych w różnych okolicznościach. Nie jest to jednostkowa wypowiedź.

W rozdziale dziesiątym De tralatione Bibliae wyjaśnienie jest nieco bardziej rzeczowe. Powiada bowiem Sutor, że rozróżnienie na vates i interpretes ma zastosowanie wyłącznie do tych prac przekładowych Hieronima, których materią nie było Pismo Święte. Tłumacząc Orygenesa, św. Hieronim mógł korzystać z możliwości, które to

4 Opus epistolarum Des. Erasmi Roterodami, denuo recognitum et auctum per P. S. Allen, t. 2, Oxonii 1910. Listy 304 i 347, wiersze odpowiednio 88-120 oraz 57-58, 80-81, 93-96, 153-157. 
rozróżnienie dawało. Gdy jednak przygotowywał Wulgatę, gdy pracował nad przekładem tekstu biblijnego, przyjmował wówczas rolę proroka. Doprawdy, argument, który pozostawia dzisiaj wiele do życzenia. Mimo to pozostaje on typowy dla pewnej formacji intelektualnej późnego średniowiecza i wczesnej nowożytności.

Dziś mało znany i w zasadzie zapomniany komentator Psałterza z końca XV wieku Jaime Pérez z Walencji w swoich Expositiones in Psalmos z 1484 roku w gruncie rzeczy robi coś analogicznego do Sutora. Znowu, próbując rozjaśnić rozróżnienie św. Hieronima, wyróżnia dwa rodzaje interpretatio i powiada, że jedna interpretatio to interpretatio linguarum, druga natomiast to interpretatio sermonum. W wypadku pierwszej rzeczywiście chodzi o przekład jako robotę filologiczną, interpretatio linguarum to bowiem przenoszenie z jednego języka do drugiego. Natomiast interpretatio sermonum to coś, co my nazywamy komentarzem, wymienia tu zresztą Pérez glosatorów jako tych, którzy się taką interpretatio zajmują. Miejsca niejasne, wymagające komentarza podlegają interpretatio sermonum i tutaj potrzebny jest już charyzmat Ducha Świętego. Warto dodać, że rozróżnienie Péreza zostało powtórzone co do słowa w pracy, która miała dużą moc oddziaływania, zwłaszcza w pierwszej połowie XVI wieku: Vocabularius theologiae Johanna Altenstaiga z 1517 roku, słowniku późnośredniowiecznej, głównie nominalistycznej teologii. Vocabularius Altenstaiga to praca, która w dużym stopniu odzwierciedla wrażliwość filologiczną i teologiczną autorów rozmaicie zainteresowanych wówczas filologią i studiami biblijnymi. Poza Erazmem i Vallą i ich naśladowcami w zasadzie cały czas funkcjonuje przekonanie, że przekład Pisma Świętego to zadanie proroka, a w każdym razie robota dla kogoś, kto podlega działaniu, wsparciu Ducha Świętego.

Ale na tym się ta historia nie kończy. Co w związku z tym z usamodzielnieniem się filologii klasycznej, nie zaś biblijnej, o której była mowa? Tutaj stajemy w obliczu zapowiadanego na wstępie zadziwiającego zwrotu w tej historii: gdyby rację miał Sutor, a jest on tutaj rzecznikiem wciąż dominującej przedhumanistycznej formacji intelektualnej, że przekład Pisma Świętego wymaga wsparcia Ducha Świętego, a nie kompetencji filologicznych, to wówczas studia biblijne 
w tym przysłużyłyby się rozwojowi filologii klasycznej, że w ogóle by jej nie dotyczyły. Ten zaskakujący splot ujawnia się w pracy polskiego grecysty Jerzego Libana z Legnicy, który w 1536 roku publikuje apologię nowoczesnej filologii greckiej zatytułowaną Zachęta do studiów greckich ${ }^{5}$. I powiada tam wprost, że doczekaliśmy się takich czasów, gdy ktokolwiek interesujący się językiem greckim z miejsca zostaje nazwany heretykiem, schizmatykiem i zwolennikiem Lutra. Nie można dzisiaj, z goryczą wyznaje Liban, uprawiać grecystyki bez implikacji wyznaniowych, a w konsekwencji bez ryzyka oskarżeń, które nie dotyczą filologicznego warsztatu, a jedynie konfesyjnych preferencji. Jeżeli filologia grecka chce się usamodzielnić, to najpierw musi ona oswobodzić się spod jarzma, które ją ogranicza i jej szkodzi, od jarzma filologii biblijnej. Liban powiada otwarcie: studiujmy język grecki, uczmy się tego języka, podobnie zresztą jak łaciny, ale po to, aby rozumieć lepiej Homera, Ajschylosa i innych klasycznych autorów. Greka nie jest wyłączną własnością biblistów, a znawca języka greckiego nie musi być z miejsca heretykiem, schizmatykiem czy zwolennikiem Lutra. Musiało upłynąć wiele czasu, by takie obserwacje stały się oczywiste.

W wieku XV i XVI filologia i biblistyka zbliżyły się do siebie w stopniu absolutnie bezprecedensowym. Po raz pierwszy stały się zjawiskiem, które współdecydowało nie tylko o tożsamości dyscypliny akademickiej lub po prostu o specyfice zajęcia o gabinetowym zasięgu oddziaływania, ale nade wszystko wpłynęło na samorozumienie chrześcijaństwa. Nie mam tu na myśli jedynie jego habitusu kulturowego, który wyzwaniem stał się już dla św. Pawła z Tarsu. Historia tego habitusu jest wprawdzie długa, ale też dobrze znana. Wszelako ten sam św. Paweł, który do Ateńczyków mówił o ołtarzu poświęconym „nieznanemu bogu”, a właściwie to „bogom”, co z akrybią wykazał św. Hieronim, nazwał

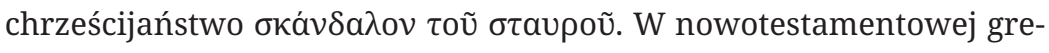
ce oznaczało to nie tylko „przeszkodę krzyża” lub barierę, ale nade

5 Carmina Sibyllae Erythręae in quibus resurectio corporum, mutatio saeculorum. Dei auentus ad iudicium, praemia \& supplitia hominum describuntur, Scholiis quae ad grammaticam attinent additis. Paraclesis item ad gręcarum literarum studiosos. Cum sermone de locunda Christi resurrectione... Cracouiae. Impressum a Floriano, millesimo quingentesimo tricesimo quinto, Christi natiuitatis anno, mensis maij ultima. 
wszystko „próg”, otwarte wejście, sposobność, którą krzyż stawał się dla zupełnie innego, nowego życia. Tutaj kompetencje filologiczne pozwalały odkryć alternatywne myślenie o tym, co dla chrześcijaństwa dystynktywne, takie myślenie, wedle którego w swojej pierwotnej, tj. historycznie nieskontaminowanej postaci chrześcijaństwo „polega raczej na uczuciach niż na sylogizmach, bardziej jest życiem niż dysputą, natchnieniem raczej niż uczonością, przemianą wewnętrzną raczej niż rozumowaniem”6 ${ }^{6}$ Bez względu na oceny tego zjawiska adwersarze filologii mieli zatem rację, iż obróci ona tradycjonalistyczny porządek do góry nogami. Granica między tym, co akademickie, fachowe, i tym, co wspólne, społeczne, po raz pierwszy zaczęła się zacierać. Jak zatem filologia miałaby się usamodzielnić, stać się samodzielną dyscypliną? Była to wielka trudność, czego żywym przykładem był wzmiankowany Jerzy Liban. Warto tu wspomnieć, że kiedy w latach dwudziestych zaczął on uczyć języka greckiego na Akademii Krakowskiej, to po kilku miesiącach został zdjęty z katedry. W zasadzie na przeszło dekadę popadł w akademicki niebyt, skoro jego wykłady zostały odwołane, oczywiście nie dlatego, że był kiepskim znawcą języka greckiego, ale widziano w nim właśnie schizmatyka i heretyka. Wobec tego, paradoksalnie, wraz ze wzrostem i rozwojem filologii biblijnej filologia klasyczna popada w coraz większe tarapaty. Co za tym idzie, gdyby Sutor miał rację, że rozróżnienie św. Hieronima wcale nie odnosi się do tłumaczenia Pisma Świętego, to lepiej by się to przysłużyło filologii klasycznej. Myślę, że tutaj postacią reprezentatywną może być również Wilhelm Budeus, przyjaciel Erazma, nie tylko znawca prawa starożytnego, ale też hellenista. Proszę zwrócić uwagę, że Budeus konsekwentnie przeprowadzał podział kompetencji, ich zawężenie: rozmyślnie był hellenistą, ale tylko w obszarze literatury niebiblijnej.

Alicja Bielak: Dziękujemy bardzo za ten przekrój narodzin filologii. Jeśli profesor Ptaszyński chciałby się do tego odnieść...

6 Erazm z Rotterdamu, Parakleza to jest zachęta do uprawiania filozofii chrześcijańskiej, [w:] tenże, Trzy rozprawy, przeł. i oprac. J. Domański, Warszawa 1960, s. 52-53. 
Maciej Ptaszyński: Bardzo chętnie. To oczywiście było arcyciekawe i niezwykle erudycyjne wystąpienie, godne mówienia o narodzinach filologii i biblistyki. Jednocześnie na początku i na końcu bardzo wyraźnie pobrzmiała diagnoza, że właściwie w XVI wieku nie możemy jeszcze mówić o narodzinach tych dyscyplin. Jako dyscypliny rodzą się one bowiem znacznie później, pewnie w drugiej połowie XVII, a nawet na przełomie XVII i XVIII wieku. Używanie tych terminów w odniesieniu do wcześniejszego okresu jest archaizmem, który dostosowuje się do pewnych klisz czy ról, którymi posługują się Erazm czy jego koledzy humaniści, tworząc swoistą tradycję krytykowania scholastyki.

W tej dyskusji, której fragmenty przedstawił Jakub Koryl, z punktu widzenia historyka widać przede wszystkim spór dwóch fakultetów. To jest spór w łonie akademii wokół tego, jak należy uprawiać naukę i kto ma do tego prawo; którymi dziedzinami wiedzy można się zajmować stosownie do pozycji zajmowanej w akademii. Z naszego punktu widzenia - ludzi zafascynowanych Erazmem - ów spór dotyczy przede wszystkim XVI wieku i w tym sensie związany jest z początkami druku wernakularnych przekładów Biblii. Oczywiście ma swoje antecedencje - sięga korzeniami niemal tak głęboko, jak instytucja uniwersytetu. Rozpoczyna się wraz z rozprzestrzenianiem się scholastyki i jej równolegle postępującą krytyką. Już w drugiej połowie XIII wieku czytamy u włoskich humanistów, że scholastycy nie znają prawdziwych języków, nie potrafią czytać greckich tekstów, a ich nauka jest barbarzyńskim powtarzaniem pewnej tradycji. Z drugiej strony scholastycy właśnie w ten sposób pojmują uprawianie nauki - jako wysublimowaną refleksję nad tekstem, która jest niezwykle wyrafinowana dzięki zastosowaniu narzędzi zaczerpniętych z tradycji.

Na przełomie XV i XVI wieku rozgorzał już bardzo wyraźny spór dwóch fakultetów w ramach uniwersytetu: wydziału sztuki i wydziału teologii. Wydział teologii posługuje się wspaniałą, wielką logiką, nawet współcześnie często trudną do zrozumienia - niełatwo nam bowiem wspiąć się na tak wysoki poziom abstrakcji, jaki osiągnęła wówczas scholastyka. Wydział artes, wydział sztuk, uważał natomiast, że należy korzystać z dorobku starożytności i że kluczem do rozumienia prawdziwego sensu tekstu jest odpowiednie odniesienie go do kontekstu 
historycznego, stąd nacisk na historyczną hermeneutykę. Przy czym chodziło nie tyle o rozumienie słów, ile sensu tego tekstu. Erazm bardzo często mówi, że znaczenie tekstu na poziomie literalnym (zwłaszcza tekstu biblijnego) nie jest najistotniejsze. Dla chrześcijanina najważniejsze jest zrozumienie sensu, między innymi przez odniesienie do historycznego kontekstu.

I tu wracamy do interpretacji historyka, który widzi w nawiązaniu Erazma do Hieronima przyjęcie pewnej roli, potrzebnej mu, żeby uwiarygodnić i uprawomocnić swoją działalność na polu do tej pory raczej zarezerwowanym dla fakultetu teologii. To pracownicy teologii mają prawo wykładać, komentować tekst, pokazywać jego wielokrotne sensy. Ich słynna czterostopniowa analiza tekstu biblijnego już Erazma nie zadowala, on chciałby raczej dobrze zrozumieć sens Biblii. Nie zgodzę się więc, że nasi humaniści na czele z Erazmem widzą w Biblii jedynie tekst.

Jakub Koryl: W przekładzie, jedynie w przekładzie widzą zjawisko tekstowej natury, czy mówimy o Wulgacie, czy o jakimkolwiek innym tłumaczeniu. To jest tutaj sprawa zasadnicza. Subtelna różnica, ale zupełnie fundamentalna. Filolodzy odkrywają na taką skalę dotychczas nieznaną hermeneutyczną tożsamość przekładów biblijnych. Można by rzec, trzymając się konsekwentnie Valli, że Wulgata nie jest Biblią - Biblia została wypowiedziana z Bożej inspiracji w języku hebrajskim i greckim, Wulgata natomiast jest po prostu tekstem albo interpretatio.

Maciej Ptaszyński: Erazm, co mu zarzucają też jego koledzy humaniści, stoi ciągle na straży wieży z kości słoniowej, w której zamknęli się przedstawiciele erudycji humanistycznej, stanowiący w sumie dosyć duży, źle opłacany odsetek pracowników uniwersytetu, poniekąd proletariat uniwersytetu XVI wieku. Jest ich wielu, bo to oni obsługują tych studentów, którzy dopiero trafiają na uniwersytet, oni uczą studenckiego abc. Dopiero po przejściu pierwszego kursu łaciny, elementów greki (o hebrajskim wówczas należy jeszcze zapomnieć) studenci trafiają na wyższe fakultety. Tylko niewielki odsetek wybierze następnie trzy lukratywne i wspaniałe fakultety: teologię dla podążających śladem najwspanialszej nauki, medycynę dla tych, którzy chcą mieć dobrze 
płatny zawód, lub prawo dla pragnących w przyszłości jeszcze lepiej zarabiać. Z punktu widzenia historii uniwersytetu jest to spór fakultetów o to, jaką rolę będą miały na uczelniach i w nauce. Spór często bardzo pragmatyczny: ile będzie katedr, jak będą opłacane, jaki wpływ będą mieli pracujący na nich wykładowcy na przyszłe losy wielkiej instytucji.

Paradoksalnie te dwie ścieżki, które Jakub Koryl zarysował bardzo trafnie i ciekawie, w oczach współczesnych są rozdzielone. Weźmy za przykład postanowienia soboru trydenckiego, który orzeka, że Biblia powinna być dostępna przede wszystkim w formie Wulgaty. Opisujące to kanony soboru sformułowano jednak bardzo szczególnie. Ojcowie w Trydencie postanawiają, że właściwie od tej pory będzie się uważać za autentyczny przekład Wulgatę. Nie mówią, że to autentyczny i najlepszy przekład - mówią, że będzie się go uważać za autentyczny, czym dość dosadnie dają wyraz dystansowi do wielokrotnie poprawionego tłumaczenia Hieronima. Niżej w tym samym artykule podkreślają także: będziemy uważać za autentyczny ten przekład, więc to on musi być wykorzystywany w kazaniach, nauczaniu i w wykładach ${ }^{7}$.

W tym niedopowiedzeniu możemy dosłyszeć wyraźne rozróżnienie funkcji. Można pokusić się o uzupełnienie tego zapisu synodu: jeżeli ktoś zajmuje się Biblią w sposób naukowy, jako teolog, to niech korzysta z tekstów oryginalnych, uprawiając poważną naukę. Wulgata powinna natomiast trafić pod strzechy. Celem tego zapisu jest zatem ujednolicenie liturgii i nauczania, aby w każdym kościele czytano te same fragmenty w identycznym brzmieniu, a wierni dostawali ten sam tekst niezależnie od szerokości geograficznej. W obrębie nauki natomiast panuje już pełna swoboda. Nawet więc w tym niezwykle restrykcyjnym momencie w dziejach sporów o Biblię, gdy sobór trydencki wypowiada się przeciwko zasadzie sola scriptura oraz za Wulgatą, owe zastrzeżenia, które wydają się zamykać pewne drzwi, są sformułowane tak, że właściwie wszystko jest ciągle otwarte. Ciągle istnieją te dwie ścieżki, więc nadal jest możliwa - przy zachowaniu ortodoksji - dyskusja na

7 Sesja czwarta, dekret II: Przyjęcie wydania Biblii zwanej Wulgata oraz o sposobie interpretacji Pisma Świętego, [w:] Dokumenty soborów powszechnych. Tekst łaciński, polski, t. 4.1, układ i oprac. A. Baron, H. Pietras, Kraków 2007, s. 213-214. 
temat tekstu, otwarta dla tych, którzy mają odpowiednie kompetencje. $\mathrm{W}$ tym sensie ciągle jest to spór o to, jakie miejsce zajmuje się w akademii i jakie w związku z tym ma się uprawnienia.

Alicja Bielak: Mówiliśmy o rozróżnieniu dyscyplin, o polemikach wokół Biblii. Teraz, idąc za tym, co powiedział profesor Ptaszyński, chciałam zadać drugie, równie przekrojowe pytanie: jak Biblia była wykorzystywana w polemikach i czy jeśli ktoś chciał zostać tłumaczem, musiał zawsze siłą rzeczy opowiadać się po którejś stronie dogmatycznej? Mówiliśmy o podziale dyscyplinarnym, ale pamiętajmy, że XVI wiek to czas podziału konfesyjnego. Jak Biblia była wykorzystywana w Rzeczypospolitej w polemikach drukowanych czy synodalnych? Czy to zawsze musiało się kończyć sporem konfesyjnym? Tym razem pytanie w pierwszej kolejności kieruję do profesora Ptaszyńskiego.

Maciej Ptaszyński: Jestem dość niewdzięczną osobą do rozpoczęcia tej dyskusji, bo chętnie bym się wypowiedział na przekór diagnozom implicite zawartym w pytaniach. Rozróżniłbym trzy nurty, które możemy dostrzec w XVI wieku: pierwszy to popularyzacja treści przekazu biblijnego; drugi to naukowy dyskurs i naukowa debata o tym, czym jest autentyczny tekst Biblii, jak należy go czytać oraz jak należy interpretować poszczególne fragmenty. Trzeci nurt można nieco umownie nazwać tożsamościowym czy konfesyjno-tożsamościowym, a obejmuje on budowanie tożsamości nowych Kościołów konfesyjnych, również Kościoła katolickiego.

Dzieje pobożności i popularyzacja biblijnych treści to nurt, w którym przede wszystkim widziałbym omawiane przez nas tłumaczenia. Ukazują się one w związku z ożywieniem pobożności piętnastowiecznej. Jeszcze przed wynalezieniem druku znamy bardzo wiele przekładów fragmentów Biblii, parafraz, różnych kompendiów biblijnych, ten tekst po prostu był bardzo potrzebny wszystkim wiernym w piętnastowiecznej Europie. Reformacja jest odpowiedzią na to wielkie zapotrzebowanie, na ożywienie pobożności piętnastowiecznej, które przejawia się w liczbie fundacji, w liczbie nowo wznoszonych kościołów, nowych ołtarzy, kulcie świętych, również w wielkim, rozbuchanym interesie 
odpustowym. Przeciwko tym zjawiskom zwraca się reformacja, będąc jednocześnie dzieckiem tego wielkiego ożywienia. Odpowiedź, którą dają reformatorzy, brzmi: trzeba na relację z Bogiem spojrzeć nieco inaczej. W tym sensie wielość tłumaczeń Biblii i spór o jej przekładanie w pierwszej połowie XVI świadczy przede wszystkim o istnieniu debaty na temat form pobożności i sposobów popularyzacji wiedzy na temat religii. Jeżeli dobrze rozumiem, to tutaj jesteśmy z doktorem Korylem bardzo zgodni - to jest pytanie o to, jak dotrzeć do ludzi, jak zaspokoić palącą potrzebę dostępu do tekstu biblijnego, obcowania z boskością i bliskości sacrum.

Pierwsze przekłady, zarówno katolickie, jak i protestanckie, wychodzą z bardzo wielu różnych tradycji i można powiedzieć, nie pasują do podziału konfesyjnego, który znamy z drugiej połowy XVI wieku. Tu docieramy do trzeciej ścieżki: tożsamościowej. Kształtujące się Kościoły konfesyjne bardzo szybko spostrzegają, że potrzebują własnego tekstu biblijnego. W tym sensie przekłady, które drukowane są w Polsce, ukazują się bardzo późno. Pierwszy całościowy przekład to jednak „katolicka” Biblia Leopolity - w tym przypadku termin katolicka należy umieścić w cudzysłowie, bo nie jest to katolicyzm potrydencki, tylko jeszcze głęboko zakorzeniony w średniowiecznej tradycji. Protestanckie Biblie nieświeska albo brzeska są początkowo odpowiedzią na żądania formułowane przez Kalwina i reformowanych przywódców protestantyzmu z zachodniej Europy od połowy XVI wieku. Kalwin pisze w 1555 roku kilka bardzo wyraźnych listów do przywódców Kościoła protestanckiego w Polsce, mówiąc: musicie przełożyć Biblię, jeśli chcecie stworzyć Kościół, własną tożsamość, własną organizację. Podstawą i warunkiem tych procesów jest tekst biblijny w języku ojczystym, wernakularnym, powszechnie dostępny dla wiernych. W tym sensie każdy Kościół, i to już wiadomo w połowie XVI wieku, musi przekładać Biblię na własne potrzeby, po to, żeby zaistnieć, żeby uchodzić - również we własnych oczach - za prawdziwą, autentyczną instytucję.

I tutaj można nawiązać do ostatniej części pytania doktor Bielak. Powiedziałbym, Biblia paradoksalnie niemal nigdy nie była przedmiotem żywych dyskusji na synodach. Gdy spojrzymy na synod jako na instytucję administracyjną Kościoła, która zbiera się raz albo kilka 
razy w roku we wszystkich Kościołach protestanckich od połowy XVI wieku (regularnie od roku 1557 z niewielkimi przerwami), zobaczymy, że dyskusje na temat tego, jak przekładać poszczególne frazy, raczej nie występują. Oczywiście zdarzają się takie momenty, na przykład gdy Szymon Budny publikuje swój przekład w roku 1572, ogólna dyskusja na temat przekładu znajduje odzwierciedlenie także w obradach synodu, jednak przekład Biblii nie jest tematem, którym synod zajmuje się regularnie.

Zazwyczaj synod porusza sprawy organizacji, dyscypliny, porządku czy funkcjonowania Kościoła. To nie jest forum, na którym mają się odbywać ważne dyskusje teologiczne i filologiczne. Wszyscy wiedzą, że takich dyskusji nie odbywa się coram publico. Na synodach Kościołów reformowanych obecni są również świeccy, którzy mają pełne prawo w nich uczestniczyć. Żaden pastor czy przywódca duchowy kościoła nie będzie uważał, że w obecności świeckich patronów należy roztrząsać sprawy przekładu Biblii oraz głębokie zagadnienia teologiczne. Raz doszło do takiej dyskusji na sejmie piotrkowskim w roku 1565. Na sejm przybyli szlacheccy patroni ze swoimi pastorami i urządzili również synod w przerwach obrad sejmu. To jest moment znaczący, gdyż Kościół reformowany małopolski rozpada się na dwie struktury, antytrynitarzy i tę ortodoksyjnie kalwińską. Wiodące pozycje w Kościele reformowanym obejmują wówczas antytrynitarze, więc kalwiniści decydują się na secesję, pociągając za sobą część świeckich patronów. Właśnie dzięki temu Kościół zostaje jednak Kościołem kalwińskim, a antytrynitarze są przez następne sto lat stopniowo spychani na margines w wyniku wewnętrznej walki.

Na synodzie odbytym podczas sejmu w 1565 roku dochodzi do autentycznej, żywej dyskusji teologicznej, lecz ona tylko zniechęciła szlacheckich patronów. Tak o tym pisze papieski nuncjusz: zniechęceni patroni uznali, że lepiej wrócić do katolicyzmu, gdzie nie ma takich sporów ${ }^{8}$. Oczywiście, nie ma sensu tworzyć reguły na podstawie pojedynczego

8 Zob. Pamiętniki o dawnéj Polsce z czasów Zygmunta Augusta obejmujące listy Jana Franciszka Commendoni do Karola Borromeusza z Biblioteki Barberińskiej, t. 1-2, wyd. J. Krzeczkowski, M. Malinowski, Wilno 1851, t. 2, nr 131, s. 167-169 (Piotrków, 25 IV 1565). 
przypadku, tym bardziej, że historia ta jest zapewne apokryfem nuncjusza. Pokazuje ona jednak fenomen, który rozumieli wszyscy w wiekach XVI i XVII - synod, na którym są obecni również świeccy, synod, którego postanowienia są często dokumentowane w różnego rodzaju biurokratycznej produkcji, nie jest miejscem na prowadzenie bardzo żywych dysput teologicznych na temat sporu biblijnego. W tym sensie wróciłbym do diagnozy, którą można wyczytać w postanowieniach Trydentu. Pod wpływem podziałów konfesyjnych drogi nauki i katechezy się rozchodzą. Dyskusja nad Biblią, jej treścią, znaczeniem oraz przekładem niektórych fragmentów trafia do dyskursu naukowego, a czasami polemicznego, podporządkowanego budowaniu własnej tożsamości. Teksty biblijne są oczywiście wykorzystywane w polemikach publikowanych wówczas w całej Europie, które w XVII wieku dzięki rozpowszechnieniu i umasowieniu druku stają się niezwykle obszerne. Oczywiście, teksty i tłumaczenia biblijne są tam wykorzystywane masowo.

Alicja Bielak: Może doktor Koryl dysponuje ciekawym przykładem dysputy zborowej, podczas której fragmenty Pisma Świętego były poddawane dyskusji? Czy również zgodzi się Pan, że filologiczna analiza Biblii stawała się punktem zapalnym polemik jedynie wewnątrz wąskiego kręgu akademickiego?

Jakub Koryl: Pyta pani, czy w kręgu tak zwanej administracji zborowej lub synodalnej prowadzono takie dyskusje? Tutaj zgodzę się z profesorem Ptaszyńskim. To nie było właściwe miejsce dla takich rozmów, co jednak nie oznacza, że Pismo Święte stawało się przedmiotem dyskusji wyłącznie w dysputach międzywyznaniowych. Istnieje jeszcze etap pośredni. W związku z tym chciałbym przywołać dwa szczegóły - dobrane wprawdzie arbitralnie, ale są one na tyle miarodajne, że mogą nam powiedzieć coś więcej w kwestii, o której rozmawiamy.

W połowie XVI wieku nasz Jan Łaski młodszy dociera wreszcie z Fryzji na Wyspy Brytyjskie i zakłada zbór cudzoziemski w Londynie. Na jego potrzeby pisze swoją, być może najważniejszą, a na pewno jedną z najważniejszych prac teologicznych pt. Forma ac ratio tota ecclesiastici 
ministerii, czyli Forma i porządek posługi kościelnej ${ }^{9}$. W ramach tego projektu eklezjologicznego Łaski wpada na pewien w zasadzie bezprecedensowy pomysł. Mianowicie zakłada instytucję profecji (po łacinie profetia). Na czym ona polegała? Były to cotygodniowe spotkania w ramach zboru cudzoziemskiego, a sądząc po tym, jak Łaski wyjaśnia ich sposób działania, były to na dobrą sprawę małe sympozja hermeneutyczne. Spotykano się wiec co tydzień i dyskutowano rozmaite miejsca z Pisma Świętego.

Istotny jest tutaj pewien szczegół - Łaski jednoznacznie podkreśla, że odpowiedzialnością za dobór tematów komentowanych miejsc z Pisma Świętego nie są obarczeni wyłącznie ministrowie, ci najwyżej stojący w hierarchii zboru, ale w zasadzie wszyscy, nawet szeregowi członkowie. Każdy, krótko mówiąc, miał prawo poddać pod dyskusję jakiś fragment Pisma Świętego. Łaski wyjaśnia, że nie chodzi tutaj o czcze deliberacje, raczej o to, żeby na drodze czynnej akumulacji wiedzy dojść do wspólnej wykładni newralgicznych miejsc Pisma Świętego, aby w ten sposób - i na to zwraca uwagę bardzo mocno - zbudować indywidualnie członka zboru, a zarazem petryfikować tożsamość zbiorową, która swoje oparcie znajduje właśnie na wspólnym rozumieniu Pisma Świętego. Jestem skłonny uznać to za elementarny i nieredukowalny punkt wyjścia dla wszelkich dyskusji na temat Pisma Świętego, które toczono w XVI wieku. Instytucja, którą zakłada Łaski, to swoisty trening egzegetyczny. Dla wszystkich, nie tylko najwyżej postawionych członków zboru.

Coś podobnego odnajdujemy mniej więcej sześćdziesiąt lat później w Rakowie - w latach 1606-1609 odbywają się tam tak zwane exercitationes, spotkania treningowe, które pod pewnymi względnymi bliźniaczo przypominają to, co wymyślił Jan Łaski w Londynie. W Rakowie również dyskutowano wybrane fragmenty Pisma Świętego. A uprzedzając pytanie, czy były jakieś szczególnie newralgiczne miejsca - w zasadzie należałoby zadać je każdemu członkowi zboru z osobna: co go będzie interesować, co mu wyda się niejasne, z jakiegoś powodu warte osobnego omówienia. Exercitationes Racovianae są o tyle ciekawszym

9 Forma ac ratio tota ecclesiastici ministerii [...], [brak miejsca druku] 1550. 
przykładem niż Forma ac ratio, ponieważ wiemy, jak one w praktyce wyglądały, znamy ich przebieg. Podobną wiedzą na temat londyńskiej profecji Łaskiego niestety nie dysponujemy. Nie udało mi się dotrzeć do żadnych dokumentów źródłowych, które mogłyby tę sprawę rozświetlić. To bardzo ciekawe, rodzi mniej lub bardziej ambitne domysły. Być może londyńskie archiwa pozwoliłyby takie hipotezy zweryfikować.

Jak natomiast działało to w Rakowie? Exercitationes były w zasadzie praktycznym zastosowaniem tego, na co wpadł kilkanaście lat wcześniej Faust Socyn w De Sacrae Scripturae auctoritate ${ }^{10}$ i nieco później $\mathrm{w}$ Lectiones sacrae ${ }^{\mathbf{1 1}}$. Socyn nie był filologiem wybitnym, ani nawet utalentowanym. Jeśli jednak, pomimo czasem zawstydzających usterek filologicznych w jego komentarzach, pozostawał on spadkobiercą Valli i Erazma oraz postacią o doniosłej roli w nowożytnej historii hermeneutyki, to dlatego iż tekstową naturę przekładu biblijnego potrafił ujawnić i uzasadnić samodzielnie. W De Sacrae Scripturae auctoritate Socyn mówi otwarcie, że Wulgatę należy czytać tak, jak każdy inny tekst, czyli stosować dokładnie te same kryteria egzegetycznej weryfikacji i falsyfikacji. Na najbardziej elementarnym poziomie Wulgata niczym się nie różni od Wergiliusza, Cycerona i innych. Zachodzi między nimi w zasadzie jedna różnica: w odróżnieniu bowiem od przykładowo Eneidy Wulgata pomyślnie przechodzi test filologicznej i historycznej zgodności na wszystkich wyznaczonych przez Socyna poziomach. Wniosek z tego płynie dwojaki. Po pierwsze, trzeba przejść filologiczny i egzegetyczny trening, by czytać z krytycznym rozumieniem Pismo Święte. Po drugie, dzięki takiemu treningowi autorytet doktrynalny chrześcijaństwa, zamiast być autorytarny, stawał się w ocenie socynian autorytetem prawdziwie autorytatywnym. To znowu subtelne, ale hermeneutycznie niezwykle doniosłe okrycie. Tworzyło ono bowiem ważny precedens nie tylko dla Spinozy albo dla oświeceniowej krytyki chrześcijaństwa, ale również dla krytyki historycznej, którą uprawiali teolodzy liberalni na przełomie XIX i XX stulecia. Osobna sprawa to skala kosztów, które pociągały za sobą nowe kryteria autorytatywności tekstu biblijnego,

10 De Sacrae Scripturae auctoritate [...], Amsterdam 1588.

11 Lectiones sacrae [...], Raków 1618. Tekst powstał prawdopdobnie około 1603 roku. 
skoro w racjonalizacji objawienia uwadze uchodziło na dobrą sprawę pierwotne, kerygmatyczne doświadczenie chrześcijaństwa.

Exercitationes Racovianae to praktyczne zastosowanie odkryć Socyna w dziedzinie egzegezy Pisma Świętego, przepraszam, egzegezy przekładu Pisma Świętego, bo socynianie, co ciekawe, zadowalali się jednak Wulgatą, bardzo rzadko sięgali do tekstu greckiego, o hebrajskim nie wspominając. Exercitationes ukazują krytykę historyczno-racjonalną w działaniu jako statutowy dla socynian trening egzegetyczny w ramach zboru, to swoista propedeutyka polemiki wyznaniowej, a więc też doktrynalnej. Na takich treningach wykształcali się reprezentanci zboru, którzy wychodzili już poza szkołę, synod i granice konfesyjne, by na forum międzywyznaniowym reprezentować swoje środowisko. Przykładem tego niech będzie kolokwium rożnowskie między antytrynitarzami i katolikami z $1660 \mathrm{roku}^{12}$. Przykładem tego przypuszczalnie byłoby także słynne Colloqium charitativum secundum, gdyby tylko dopuszczono tam do głosu spadkobierców Socyna...

Maciej Ptaszyński: To jest rzeczywiście arcyciekawa wizja, którą przedstawił Jakub Koryl, wiodąc nas od świętego Hieronima przez Erazma ku Socynowi i socynianizmowi, czyli takiej „ulepszonej” wersji antytrynitaryzmu, która pojawia się na przełomie XVI i XVII wieku w Polsce, by następnie silne oddziaływać na myśl europejską drugiej połowy XVII wieku. Rzecz jest ciekawa. Pozwolę sobie dorzucić dwie drobne uwagi czy dwa komentarze historyka do tego wywodu - jeżeli chodzi o Łaskiego, którego profecję tak pan połączył z antytrynitarzami, tutaj należy zastrzec dwie rzeczy, które są dla nas oczywiste, a dla słuchaczy mogą być trochę mylące. Oczywiście Jan Łaski jest arcywrogiem rodzącego się antytrynitaryzmu...

Jakub Koryl: Tak, tak oczywiście.

12 Zob. Summa colloquii Roznoviae habiti, communicata ab Andrea Jovedeczio, [w:] Andreae Wengerscii Libri quattuor Slavoniae reformatae, praefatione instruxit I. Tazbir, Varsoviae 1973, s. 538-586. 
Maciej Ptaszyński: ... jest absolutnie ortodoksyjnym kalwinistą i jego powrót do Polski w roku 1556 opóźnia wszelkie próby rozpoczynania dyskusji wokół fundamentów myśli kalwińskiej czy myśli reformowanej. Powrót Łaskiego kładzie tamę dialogowi, który wówczas toczy się pomiędzy reformowanymi a braćmi czeskimi. Łaski wbrew ekumenicznej wizji, która go otacza, był bowiem człowiekiem ortodoksji. Mimo łagodności jego wypowiedzi i stylistyce irenicznej, w którą lubi ubierać swoje wystąpienia, tak naprawdę dążył wówczas do podziałów, mając bardzo jasną wizję Kościoła reformowanego i podporządkowania mu innych wyznań w Polsce. Dlatego do rozpadu dochodzi po śmierci Łaskiego, która nastąpiła w 1560 roku. Jego zgon oznacza początek kryzysu, walki o przywództwo, stworzenie luki, która pozwala na objęcie władzy w zborze reformowanym przez postaci, które są zwolennikami nieortodoksyjnej chrystologii, jak na przykład przez Jana Biandratę, osobistego wroga Jana Kalwina. To tak ad vocem do tego wywodu...

Czy zasady opisane przez Łaskiego w Forma ac ratio były stosowane w Anglii? Można zadać także szersze pytanie: czy to, co Łaski pisze w Forma ac ratio, czerpiąc z różnych istniejących porządków kościelnych (między innymi Johannesa Brenza), było w ogóle stosowane? Z jednej strony Łaski ogłasza ten druk w momencie, gdy opuszcza Anglię. Z drugiej strony mógł przecież odzwierciedlić w Forma ac ratio różne praktyki, które wcześniej stosowane były przez niego w tym zborze wygnańców. Jak słusznie zauważył Jakub Koryl, dotychczas nie znamy odpowiedzi na te pytania.

Jeszcze słowo o naszych antytrynitarzach - Socyn i jego następcy kładą podwaliny pod bardzo wpływową szkołę, o czym również niedawno Jakub Koryl pisał bardzo przekonująco ${ }^{13}$. Zasługą Socyna jest stworzenie początków klasycznej hermeneutyki historyczno-filologicznej. Staje się ona bardzo modna w pewnych kręgach intelektualnych w Europie w XVII wieku i w gruncie rzeczy sprowadza się do przekonania, że Biblia jest tekstem historycznym i nie ma wiele wspólnego z wiarą.

13 J. Koryl, Hermeneutyka braci polskich, [w:] Antytrynitaryzm w pierwszej Rzeczypospolitej w kontekście europejskim. Źródła-rodzaj-oddziaływanie, red. M. Choptiany, P. Wilczek, Warszawa 2017. 
Wszystkie obrazy, które wywodzimy z Biblii, czyli na przykład naiwne wyobrażenie Boga jako surowego pana z brodą, nijak mają się do tego, czym naprawdę jest Bóg oraz czym jest wiara. Biblia nie opowiada nam o Bogu, lecz o pewnej historii, a wiara jest natomiast przeżyciem intelektualnym, wewnętrznym człowieka. Te dwie płaszczyzny niemal się nie przecinają - to konsekwencje, które w XVII wieku niektórzy myśliciele wywiodą z tej nowej hermeneutyki. Do wiodących myślicieli należy zarówno Baruch Spinoza, który, co prawdopodobne, inspirował się pewnymi tekstami polskich antytrynitarzy działających wówczas w Niderlandach, jak i John Locke oraz ojcowie liberalnej myśli. Podobnie jak antytrynitarze, dążyli oni do rozdzielnia porządków wiedzy i wiary, a siłą rzeczy - do związanego z tym postulatu uwolnienia wiedzy z oków, które narzucała jej teologia.

Jakub Koryl: Na prawach ciekawostki - przypomniało mi się określenie, którym jeden z adwersarzy Johna Locke’a go opatrzył. Nazwał go małym rabinem z Rakowa, co doskonale pokazywało, w jakim stopniu wczesne angielskie oświecenie było przesiąknięte zjawiskami, które rodziły się w Rzeczypospolitej.

Alicja Bielak: Dziękuję bardzo za ten ciekawy dwugłos, a teraz zapraszam do dyskusji.

Tadeusz Rubik: Chciałem dodać à propos dekretu soboru trydenckiego, że tam się spierały bardzo różne stronnictwa i dekret miał zadowolić wszystkich, dlatego tak naprawdę nie zawierał szczególnie dużo treści. Ale to też jest casus Jakuba Wujka, tego jak ten przypadek był później rozumiany. W zasadzie można interpretować cenzurę jego Biblii, dość dotkliwą, jako różnicę w interpretacji tego dekretu, to znaczy - na co mógł sobie pozwolić z tekstami niełacińskimi.

Profesor Ptaszyński powiedział o Biblii Leopolity z 1561 roku jako o katolickiej w cudzysłowie, jak rozumiem w kontekście postępującej konfesjonalizacji i rodzącej się tożsamości wyznaniowej, ale ona też jest postrzegana jako faktycznie „katolicka partyzantka”, bo to jest czas, kiedy w roku 1558 Stanisław Hozjusz napisał De expresso Dei verbo, 
w którym bardzo krytycznie wyrażał się o wszystkich tłumaczeniach Biblii, i Biblię Leopolity postrzega się właśnie jako samowolę katolików na bardziej skrypturalnym kursie. Czy panowie się może z tym zetknęli?

Jakub Koryl: Szybko odpowiem: nie, nie spotkałem się, poza tym, że zasadniczo każde inne tłumaczenie niż Wulgata było momentalnie na cenzurowanym, nie mówiąc już o tłumaczeniach wernakularnych, które co najmniej w dwójnasób były dla katolików niebezpieczne. Tutaj Hozjusz rzeczywiście był taką postacią... (może nie będę używał zbyt mocnych słów). Jako reprezentant i rzecznik bardzo specyficznej formacji hermeneutycznej i wyznaniowej pozostawał on współodpowiedzialny za to, że droga katolickiej Biblii wernakularnej okazała się w Rzeczypospolitej nad wyraz długa i trudna. Gdy już się pojawiła z oficjalną aprobatą, to okazała się zjawiskiem spóźnionym w przybliżeniu o trzydzieści lat, które wówczas znaczyły chyba znacznie więcej, niż bylibyśmy skłonni i zdolni dzisiaj sądzić. Wedle ówczesnej miary owe trzydzieści lat oddzielało dwie epoki w historii chrześcijaństwa. Kto wie, czy z powodu tego opóźnienia Biblia Wujka nie stała się także zjawiskiem niespełnionym pod względem jej zdolności międzywyznaniowego oddziaływania. Granice konfesyjne były wówczas już trwale wyznaczone, zaś wszelkie próby odnalezienia kompromisu, który pozwalałby te granice negocjować, raczej tolerowano, niż afirmowano. Dziś możemy jedynie spekulować, jak potoczyłyby się losy rodzimego chrześcijaństwa, gdyby Biblia Wujka ukazała się nawet w tej samej postaci, ale gdzieś pomiędzy Biblią brzeską a pierwszymi przekładami Szymona Budnego.

Maciej Ptaszyński: „Katolicka partyzantka” to rzeczywiście trafna metafora. Tego, że owo tłumaczenie jest taką partyzantką, dowodzi również to, jak mało o tej Biblii wiemy. Jest niesygnowana, Leopolitę opatruje się dodatkiem „tak zwany”, bo po przedmowie, którą Biblia jest opatrzona, znajdują się tylko inicjały. I to już sygnał, jak bardzo ten tekst jest wbrew duchowi czasu, w tym sensie, że dokładnie takich praktyk zakazuje sobór trydencki. Oprócz nakazu wykorzystywania w nauczaniu tylko Wulgaty, sobór mówi również: należy przede wszystkim kontrolować wszystkich drukarzy, nie wolno wydawać druków bez zgody lokalnej 
zwierzchności, nie wolno ich publikować anonimowo lub bez miejsca i daty wydania. Rzeczywiście, tekst się ukazuje - można powiedzieć nieco metaforycznie - jako martwe dziecko, w sytuacji, kiedy oficjalnie w Trydencie zakazuje się publikowania tego rodzaju tłumaczeń. Co prowadzi też do pytania o długą recepcję reform Trydentu w Polsce, która rzeczywiście zachodzi w końcu XVI wieku, a nawet w XVII i często przy wielkim oporze kleru katolickiego.

Powiedziałem też, że ona jest w cudzysłowie katolicka w trochę innym sensie. Chodziło mi o to, że określenie „katolicki” można postrzegać jako konfesyjne, co oczywiście jest niezwykle delikatną kwestią dotyczącą ciągłości Kościoła chrześcijańskiego od czasów Chrystusa i apostołów aż po współczesność. Jednak w wyniku przemian reformacyjnych zachodzących w Kościołach protestanckich również bardzo silnie zmienia się i konfesjonalizuje - jak pan powiedział - również Kościół rzymski. W tym sensie, gdy mówimy „Kościół katolicki”, należałoby właściwie odnosić to określenie do Kościoła potrydenckiego, do Kościoła, który się reformuje i wychodzi z przemian konfesyjnych i staje się takim samym Kościołem konfesyjnym, jak inne kościoły protestanckie rywalizujące z nim w drugiej połowie wieku XVI, wykorzystującym też Biblię jako fundament budowania własnej tożsamości oraz środek ewangelizacji wiernych. To oczywiście zupełnie inna wizja Kościoła od Kościoła rzymskiego przedreformacyjnego, późnośredniowiecznego.

Ks. dr hab. Stanisław Wronka: Była tutaj mowa o renesansie antyku i związku z kwestią biblijną. Jeśli dobrze rozumiem: najpierw było zainteresowanie literaturą klasyczną grecką, rzymską, które potem przełożyło się na Biblię, a z kolei to przełożenie na Biblię zahamowało zainteresowanie antykiem. Czy tak mniej więcej to wyglądało?

Jakub Koryl: Tak, w uproszczeniu, ale mieszczącym się w granicach sensowności, tak właśnie można byłoby to opisać. Chociaż, prawdę mówiąc, nie jestem w stanie precyzyjnie wskazać, w którym momencie doszło do tego drugiego etapu, od zainteresowania starożytnością grecko-rzymską do zainteresowania starożytnością judeo-chrześcijańską, tak bym powiedział. W XV wieku to w gruncie rzeczy kilka rozrzuconych 
wysepek: oczywiście wspomniany Valla, poza tym Gianozzo Manetti, to Pico della Mirandola, Marsilio Ficino sporadycznie, ale też komentuje Pismo Święte. To są wszystko rozproszone zjawiska i postacie nietworzące w zasadzie żadnego spójnego zjawiska czy tym bardziej wspólnego frontu. To wszystko petryfikuje się i przybiera jakieś bardziej sensowne, wyraziste kształty dopiero w XVI wieku. Zmiana, która wówczas przychodzi, wciąż jest jedynie częściowa, skoro z wymienionych autorów w grze pozostał w zasadzie tylko Valla. Erazm już pod koniec XV wieku mówi o sobie otwarcie, że jest obrońcą Valli jako humanistycznego herezjarchy. Wiedział już bowiem, że Valla wśród swoich współczesnych nie był postacią - by ująć to eufemistycznie - zgodnie akceptowaną. Erazm bardzo szybko zmienia swój stosunek do Poggia, którego wcześniej podziwia. Kiedy dowiaduje się, że pomiędzy nim a Vallą wywiązała się ostra polemika, zaczyna na temat Bracciolliniego wypowiadać... No cóż, ciekawi mogą samemu doczytać, co wypowiada, robi to z wielką filologiczną klasą i niemniejszą jadowitością. To wyszukane, chyba też hermetyczne inwektywy, nie dla byle jakiego antagonisty, myślę, że godne prawdziwie epokowego sporu, który Erazm odkrył i na nowo rozniecił kilkadziesiąt lat po zakończeniu jego pierwszej fazy. W XV wieku nowa filologia biblijna jest nieusystematyzowanym, niespójnym, sporadycznym i rozporoszonym zjawiskiem. Zarazem jednak skala wyzwania, które chrześcijaństwu rzucił Valla, dowodzi, że nie było to zjawisko marginalne. Bynajmniej. Co za tym idzie, nie potrafię wyjaśnić, co i nade wszystko kiedy spowodowało, że oprócz Ajschylosa, Plutarcha w podobny sposób i z pomocą analogicznych narzędzi zaczęto czytać również św. Jana. Źródła tej zmiany, jak sądzę, wykraczają daleko poza zarówno historię filologii u progu nowożytności, jak i jej zmieniających się zdolności akomodacyjnych.

Ks. dr hab. Stanisław Wronka: Zainteresowanie filologią biblijną zahamowało z kolei zainteresowanie antykiem klasycznym? Po prostu siły zostały zwrócone w inną stronę?

Jakub Koryl: W tym względzie przywoływana przeze mnie działalność Jerzego Libana z Legnicy jest, co jeszcze raz podkreślę, znamienna 
i miarodajna dla zjawiska, o którym mówimy. Mniej więcej połowę jego Zachęty do studiów greckich, niewielkiej apologii hellenistycznego kształcenia wydrukowanej w formacie octavo, wypełnia wyliczanie zgubnych konsekwencji, które dla hellenistyki przyniosło powstanie humanistycznej filologii biblijnej. Kto po greckich edycjach Nowego Testamentu zajmował się językiem greckim, ten, co pokazuje przykład Erazma, mógł w najlepszym razie liczyć ze strony swoich adwersarzy na miano greculus. To oczywiście etykieta zaczerpnięta jeszcze od św. Augustyna, zawsze pogardliwa w swojej wymowie, to jakiś „greczyk”, mały Grek. Spośród wszystkich inwektyw, z jakimi musiał się mierzyć ktoś, kto po Erazmie zajmował się językiem greckim, ta była chyba najmniej dotkliwa. Schizmatyk, heretyk, zwolennik Lutra: oto zarzuty, jakie stawiano częściej i które już wymiernie wpływały na spowolnienie rozwoju grecystyki w czasie reformacyjnego kryzysu, jak pokazuje przykład Jerzego Libana. Ten, w odróżnieniu od Erazma, biblistą ani nie był, ani nie chciał być.

Profesor Ptaszyński zwraca uwagę, że mówienie o filologii klasycznej to w XVI wieku anachronizm. Zgoda. W tamtym czasie jeszcze nie funkcjonowała ona jako samodzielna dyscyplina, podobnie zresztą jak każda inna filologia, bardzo długo, bo aż do XIX wieku pozbawiona akademickiej autonomii. W okresie, o którym mówimy, cały czas lepiej bądź gorzej wiodło się sztukom wyzwolonym, nade wszystko trivium. Na pośredniowiecznym uniwersytecie wciąż uczono bowiem gramatyki, retoryki, dialektyki. Nieśmiało i z różnym skutkiem włączano tam naukę języka greckiego w zakresie większym niż tylko jako propedeutyka dla nauki łaciny. W ramach humanistycznych studia humanitatis język grecki zaczął odgrywać niepomiernie większą, niemal dystynktywną rolę dla ruchu humanistycznego. U progu reformacji znajomość greki funkcjonowała w świadomości zbiorowej jako cecha pozytywnie odróżniająca humanistyczną formację intelektualną od reprezentantów barbarzyńskiej, jak wówczas sądzono, formacji scholastycznej. Przykład bazylejskiej ekipy pracującej z Erazmem nad pierwszym wydaniem greckiego Nowego Testamentu, tej samej, która już w 1514 roku ochoczo nazywała siebie „erazmianistami”, ilustruje, że już wtedy greka przestawała być jedynie ekwipunkiem w tym, co Kant rozumiał przez 
spór fakultetów, a co w XV wieku zwykło się analogicznie nazywać disputa delle arti. Grecystyczne kompetencje filologiczne były zatem przekazywane, choć w zupełnie innym trybie, zakresie i z innym rezultatem niż dzisiaj.

To wszystko nie oznacza, że kryzys reformacyjny nie przewartościował humanistycznych priorytetów edukacji językowej (wiemy o tym przecież doskonale) albo że nie zmienił często diametralnie odmiennego pojęciowego instrumentarium humanistów, o czym wciąż wiemy chyba dużo mniej niż powinniśmy. Nie oznacza to również, że nie zaczęto pod wpływem tego kryzysu poszukiwać dla hellenistyki samoutwierdzenia i akademickiej samodzielności. Gdy nasz Liban inkryminuje wroga greki tyleż erazmiańską, co zwodniczą dla nas etykietą graecomastix, a więc tego, który „z nienawiścią chłoszcze język grecki”, to stawką takiej konfrontacji bynajmniej nie jest idea uniwersytetu jako takiego, a tym bardziej kantowski spór o pierwszeństwo jednej dyscypliny przed drugą. Jeszcze dwie dekady wcześniej funkcjonalnym synonimem wspomnianej etykiety graecomastix był byle jaki teolog, theologaster, czyli „teolożek” albo raczej „teologiżyna”. Liban deklaruje, że języka greckiego wolno uczyć się również po to, aby czytać tragików albo Homera, nie zaś tylko dlatego, by czytać Nowy Testament. Dla Libana graecomastix nie jest adwersarzem humanistycznego zwrotu w biblistyce, to wróg Homera i innych greckich klasyków. To subtelna zmiana, która za sobą pociąga coś więcej niż przekonanie, jakoby tożsamość wyznaniowa akademika nie powinna odgrywać w jego pracy żadnej roli. Stawką jest tutaj precyzyjnie zakreślony zakres jego kompetencji oraz obszar ich zastosowania, z którego wyłącza się źródła o wyznaniowych implikacjach. Liban domaga się czegoś, co w tamtym czasie i na taką skalę było w gruncie rzeczy niemożliwe do zrealizowania. Nie chcę być źle zrozumiany. Liban był świetnym grecystą, rozumiał język grecki i potrafił w nim myśleć, kto wie czy na taką skalę nie był w tym odosobniony w ówczesnej Polsce. W każdym razie nikt więcej nie przychodzi mi do głowy. Mam wrażenie jednak, że chyba nie dorósł on do zmiany, którą chciał sprokurować, nie potrafił intelektualnie sprostać wielkiemu wyzwaniu, z którym się mierzył. Jego racje są niedostateczne, a z pewnością już wówczas zdecydowanie rozczarowujące. Liban sięgał 
bowiem jedynie po argumenty protagonistów wczesnego ruchu humanistycznego, na domiar złego o antycznym rodowodzie: po wypowiedzi Piera Paola Vergeria, a nade wszystko Guarina z Werony na temat użyteczności języka greckiego dla edukacji w zakresie studia humanitatis. Dla historyka renesansowego humanizmu to zapewne ciekawe racje, obawiam się jednak, że dla nikogo więcej... W latach trzydziestych XVI wieku, w dobie reformacyjnego kryzysu to był anachroniczny i pragmatycznie jałowy nonsens. W tym przywiązaniu Libana do Vergeria, Guarina, o patronujących im Horacym i Kwintylianie nie wspomnę, było coś z intelektualnej donkiszoterii. Czy Liban wypowiadał się wyłącznie w swoim własnym interesie, czy w obronę brał także uprawianą przez siebie dyscyplinę, to sprawa w tym momencie drugorzędna. Znacznie ważniejsze, również dla historii lub prehistorii filologii greckiej, jest to, że pojawiła się potrzeba uzasadnienia uprawiania hellenistyki pozbawionej implikacji wyznaniowych w czasie, gdy różnica wyznaniowa stawała się głównym czynnikiem motywującym ówczesną politykę intelektualną. Więcej nawet - brak owych implikacji miał być wówczas, co podkreślano, dla hellenistyki wielką i chyba jedyną szansą. Wspomniany przeze mnie Budeus może być tutaj przykładem, że taka filologia była możliwa.

Maciej Ptaszyński: Z tym ja się z kolei muszę nie zgodzić. Rzeczywiście, to było możliwe. Pytanie, na ile takie sądy są rzeczywiście wyrazem partykularnych interesów, a na ile reprezentacyjne dla szerszej grupy. Wydaje mi się, że również dla tych najwcześniejszych, czternasto- czy piętnastowiecznych humanistów, może od Petrarki, studiowanie tekstów starożytnych, które się odkrywa i odczytuje na nowo, by uczyć się z nich starożytnych języków, jest głęboko zanurzone w potrzebie odkrywania autentycznego chrześcijaństwa. Pierwsi humaniści poszukują tekstów starożytnych, badają je, a nawet uczą się ich często w określonym celu i w określonym kontekście. Warto pamiętać, że poza importem tekstów platońskich i neoplatońskich po upadku Konstantynopola, najczęściej znajdowali te teksty w klasztornych skryptoriach. Piętnastowieczni humaniści, na przykład Poggio Bracciolini, są wędrowcami przypominającymi dzisiejszych archeologów. Podróżują 
od klasztoru do klasztoru, szukają starożytnych kodeksów, w nich z kolei - do tej pory przemilczanych, pominiętych zagubionych tekstów, tak jak Poggio odkrywa dzieło Lukrecjusza.

To właśnie jest renesans. Głęboko zanurzono w kulturze chrześcijańskiej nawet teksty starożytnych materialistów, ateistów, wyciągane ze skryptoriów klasztornych. Na nowo odkrywano rzeczy, którymi do tej pory nikt się nie interesował. To zainteresowanie powstaje nagle, ale w przypadku większości przynajmniej humanistów, o których teraz mówimy, jest podyktowane głęboko chrześcijańskimi duchownymi potrzebami, które nasi humaniści chcą zaspokoić. Pomyślmy choćby o Petrarce, który wędruje na Mont Ventoux razem z tekstem Wyznań Augustyna pod pachą, odkrywając naturę. Otwiera tekst świętego Augustyna, szukając miejsca, które by mu skomentowało aktualne wydarzenia, i znajduje fragment, który mówi: nie szukaj przyrody, nie rozglądaj się na boki, tylko zajrzyj do wnętrza samego siebie. Petrarca wraca z tej wędrówki, która miała być odkryciem przyrody, pogrążony $\mathrm{w}$ zadumie i z takim przekonaniem, że właściwie zmarnował tyle czasu i sił, podczas gdy powinien medytować nad zbawieniem, Chrystusem, nad swoją rolą jako chrześcijanina w świecie. Wszystkie najważniejsze teksty, które dla nas tworzą obecnie humanistyczny kanon, są bardzo głęboko zanurzone w potrzebie nowego odczytania Biblii, odkrycia Biblii - i w tym sensie nie do końca bym się zgodził z diagnozą prezentowaną przez Jerzego Libana. Takie głosy się zdarzają, ale chyba są marginalne, częściej spotykane dopiero w XVII wieku, kiedy potrzeba oddzielenia świeckiego świata wiedzy od świata wiary bywa na poważnie werbalizowana przez bardzo wielu myślicieli i staje się drogą, która wiedzie nas już ku osiemnastowiecznej oświeceniowej Europie.

Alicja Bielak: Na koniec dosyć zaczepne pytanie. Czy sądzą panowie, że nasze dyskusje w badaniach na temat Biblii są przesadzone? Czy może sytuowanie źródeł polemik w samym tekście Biblii, jej przekładach i wydaniach jest zbytnio podkreślane w badaniach? Może to nie było aż tak znaczące w wiekach XVI, XVII, o czym świadczyłyby chociażby migracje tych samych rycin między edycjami Biblii różnych konfesji? 
Maciej Ptaszyński: Na pewno nasza ocena znaczenia Biblii nie jest przesadzona. O późnym średniowieczu i epoce nowożytnej nie da się myśleć, abstrahując od Biblii. To jest tekst, z którym wszyscy obcują, z którym się wszyscy identyfikują, przez pryzmat którego wszyscy patrzą na własne doświadczenie, więc to jest absolutnie słuszna perspektywa.

Pytanie, czy redukowanie tego świata polemik, świata druku tylko do interpretacji biblijnych nie jest rzeczywiście krokiem za daleko. Ja bym raczej powiedział, że w badaniach ostatnich dwóch, a może nawet trzech dziesięcioleci, odkrywa się coraz częściej suwerenność tego świata polemik. Polemiki konfesyjne bardzo często służyły wielu celom jednocześnie, co tutaj też starałem się pokazać w naszym dwugłosie. Gest antytrynitarzy czy socynian, którzy powoływali się na Erazma, czy Erazma powołującego się na Hieronima często oznaczał nie tylko autentyczne inspiracje, za którymi stała filologiczna wiedza, ale także dawał wyraz chęci autoprezentacji czy autostylizacji uprawniającej do formułowania pewnych sądów, zajęcia określonych pozycji w sporach.

W tym sensie polemiki i gesty w nich zawarte warto traktować jako suwerenne wystąpienia, niemal autoteliczne. Ich sensem oczywiście jest polemika, ale jednocześnie służyły wielu funkcjom, nie tylko zderzeniu argumentów, które w sumie często były powszechnie znane w wiekach XVI, XVII. Już po pierwszej fali polemik w drugiej połowie XVI wieku wszyscy dobrze wiedzieli, kto jakie zajmuje pozycje. Argumenty były niezmieniane od kilkudziesięciu lat, a mimo to publikowano coraz więcej polemik, walczono coraz ostrzej, a bardzo często chodziło nie o to, żeby przekonać przeciwników, lecz o to, żeby umocnić własny obóz albo zbudować własną pozycję jako wytrawnego teologa.

Często teolog, zdobywając szlify, nie tylko występował na uniwersytecie z oracjami czy dysputacjami, ale musiał też wykazywać się jako polemista, bronić własnego obozu, ogłosić całą serię polemik. Było jasne, przeciwko komu on te polemiki opublikuje: antytrynitarz musiał uderzyć w luteranów, reformowanych i katolików; katolik - w kalwinistów, luteranów i antytrynitarzy etc. Pozostawało tylko pytanie, jak ostro ten atak będzie sformułowany, jak obszernie, w których konkretnie polemistów uderzy. To też jest znak, który dla nas dziś bywa czytelny, a dla współczesnych mógł być jeszcze wyraźniejszy. Określa zamiary, 
aspiracje, pozycję autora wśród innych teologów. Często te polemiki nie wyczerpują się na odwołaniu do Biblii i czerpaniu z niej argumentów. Wręcz przeciwnie, argumenty biblijne są drugorzędne, bo są bardzo powtarzalne. Sam tekst jest przewidywalny, a znacznie ciekawsze jest to, co znajduje się wokół niego.

Ostania rzecz to kontekst materialny czy ekonomiczny. Publikowane teksty mają też wartość materialną, w ich produkcji i dystrybucji uczestniczy cała armia ludzi, co wiąże się z tym, że utwory mają swoją cenę. Często zatem logika rynku jest ważniejsza niż inspiracje biblijne, które pojawiają się na ich kartach. Ta wartość materialna stała się ostatnio dla nas, badaczy dawnej książki czy kultury szesnasto- i siedemnastowiecznych dysput, coraz ważniejsza i lepiej widoczna. Trafniej doceniamy uwarunkowania materialne i społeczne - aspekt kultury polemik, który można by nazwać pragmatycznym.

Jakub Koryl: W pełni zgadzam się z tym, co powiedział profesor Ptaszyński, nie ma tu mowy o przesadzie. Sięgnę jednak po inne racje, by nacisk położyć na jawne i ukryte implikacje proklamacyjne w zmianach, o których tutaj mówiliśmy. To komunał nietypowy, bo wyjątkowo sensowny, że przekład Pisma Świętego jest aktem założycielskim reformacji, to element konstytutywny dla Konfessionsbildung, dla tworzenia konfesji jako świadomości odrębnej określonej grupy wyznaniowej.

Mamy tutaj do czynienia z epokowym problemem, przed którym stanęli wszyscy, jak myślę, zainteresowani losem chrześcijaństwa u progu nowożytności: jaką rolę w kształtowaniu wyobrażeń i doświadczeń chrześcijańskich mogą czy też powinny odegrać kompetencje filologiczne? Innymi słowy, stajemy w obliczu pytania, kim stawał się wówczas tłumacz Pisma Świętego i jak daleko sięgały już pozagabinetowe konsekwencje jego wiedzy fachowej? Wreszcie, w jaki sposób przenieść działania fachowe na obszar doświadczeń indywidualnych i zbiorowych? U młodego Lutra jest porównanie, które szczególnie lubię. Powiada on mianowicie, że w teologii chodzi o to, by „wydobywać orzech z łupiny, ziarno z łuski i szpik z kości”14. Jestem przekonany, że

14 Dr. Martin Luthers Briefe, Sendschreiben und Bedenken, Berlin 1825, cz. 1, s. 14, 1. 41-44. 
gdy dzisiaj sięgamy po dawne przekłady biblijne, to wydobywamy właśnie orzech z łupiny, ziarno z łuski i szpik z kości ówczesnych przemian chrześcijaństwa. Przekład biblijny to swoiste laboratorium tych zmian. Jeśli zatem jest to najwłaściwsze miejsce dla stawiania pytań o specyfikę zmian sprokurowanych przez reformację, a tak właśnie sądzę, to potrzeba dyskusji o badaniach nad Biblią w XVI i XVII wieku nigdy nie będzie na wyrost.

Warto pamiętać, że pojęcia reformacji i deformacji, bo takim się również posługiwano, należały od XV wieku do żargonu technicznego teologów, były elementem języka środowiskowego, języka nazbyt abstrakcyjnego i przez to mało zrozumiałego dla tych chrześcijan, którzy żyli poza akademią, poza synodem, poza dyskusjami. W ich miejsce potrzeba było zatem pojęcia, które lepiej odpowiadałoby rzeczywistej skali zmian spowodowanych reformą chrześcijaństwa, a więc takiego, które pozwalałoby w określony i zamierzony sposób kształtować doświadczenia jednostkowe i zbiorowe, a następnie zdawać z nich sprawę. W latach osiemdziesiątych zeszłego stulecia John Bossy, wówczas jeden z czołowych angielskich historyków chrześcijaństwa zachodniego, wprowadził do słownika historiograficznego kapitalną innowację pojęciową ${ }^{15}$. W miejsce tego, co dotychczas określano mianem reformacji zaproponował on etymologicznie wieloznaczną, a przez to funkcjonalnie wszechstronną kategorię Christianity Translated. Wskazuje ona bowiem na dwa wydarzenia, których nieredukowalne powiązane ujawnia specyfikę ówczesnego chrześcijaństwa: na „przekład” jako specjalistyczną, filologiczną robotę oraz na „przeniesienie” jako pragmatyczne działanie tej pracy w przestrzeni zbiorowej. W źródłowej dla kategorii Christianity Translated łacińskiej translatio stale mowa przecież zarówno o przekładzie, jak i o przeniesieniu, czyli zmianie położenia, zwiększaniu wpływów, czy nawet o zmianie stanu. Mam wprawdzie wątpliwości, czy ta asocjacja pojęciowa jest w pełni uzasadniona dla całego chrześcijaństwa wczesnonowożytnego, ale - co działa na jej korzyść - jestem przekonany, że nigdzie indziej nie odkłada się tak obficie nasze rozumienie rzeczywistości, jak właśnie w języku

15 J. Bossy, Christianity in the West 1400-1700, Oxford 1985. 
potocznym, do którego należy również łacińskie pojęcie translacji jako przekładu i przeniesienia. Przekład Pisma Świętego to przeniesienie, epokowy dla chrześcijaństwa transfer tego, co fachowe i akademickie, w obszar doświadczeń jednostkowych i zbiorowych. Realne i wymierne zmiany w chrześcijaństwie zaczęły zachodzić dopiero wtedy, gdy wiedza fachowa filologów i teologów przestała być jedynie elementem indywidualnego bądź akademickiego wyposażenia i stawała się każdorazowo dobrem wspólnym określonych wspólnot interpretacyjnych, które nazywamy Kościołem rzymskokatolickim, ewangelicko-augsburskim, ewangelicko-reformowanym, itd. Wzmożone zainteresowanie i praca nad tłumaczeniami biblijnymi ujawnia, choć z różną intensywnością w zależności od wyznania, proklamacyjne implikacje kryzysu reformacyjnego, czyli jego priorytetową intencję, by stale przenosić kerygmat w indywidualne i zbiorowe doświadczenia chrześcijan. Jako forma pastoralnej eksplikacji objawienia tłumaczenia biblijne stają się zatem istotnym elementem proklamacji, która przynajmniej częściowo i w zamierzeniu odciąża chrześcijaństwo z dogmatycznego deponowania i apologetycznego dozoru słowa Bożego.

Przekład Biblii ilustruje, jak dotychczas gabinetowa wiedza funkcjonalnie wykracza poza swoje pierwotne zastosowanie i pragmatycznie zwiększa swoje wpływy na bezprecedensową skalę. Jeśli zatem miernikiem tej zmiany (nie chcę tu mówić o postępie lub regresie) jest wpływ na świadome postawy i mentalności zbiorowe, to za faworyzowaniem kategorii Christianity Translated kosztem tradycyjnej nomenklatury historiograficznej kryje się przekonanie, że to właśnie przekład biblijny jest kluczem do pełniejszego zrozumienia przemian ówczesnego chrześcijaństwa. Nie zabieram tutaj głosu jako rzecznik innowacji Bossiego. Zależy mi tylko na tym, by wskazać tłumaczenie Pisma Świętego jako akt źródłowy i inicjujący owe zmiany. W tym samym Piśmie, w liście do Rzymian teolodzy odnajdywali pełen semantycznych i doktrynalnych półcieni imperatyw $\mu \varepsilon \tau \alpha \mu \rho \rho \varphi 0 \tilde{\sigma} \theta \varepsilon$, przez św. Hieronima dosłownie oddany jako reformamini, który legitymizował reformę jako pojęcie przez długi czas pozostające elementem specjalistycznego żargonu teologicznego, a dopiero później jako statutowy postulat dla wszystkich chrześcijan. 
Powiedziałem, że tłumaczenie Biblii jest aktem założycielskim reformacji. Nie przypadkiem i na dobrą sprawę w imieniu swojej epoki Jakub Wujek powiada, że każda sekta ma swój przekład. W rzeczy samej, bez przekładu Pisma Świętego nie ma konfesji jako dokumentu, bez przekładu Pisma Świętego nie ma wyznania jako formy tożsamości zbiorowej i odrębnej zarazem, wreszcie bez przekładu Pisma Świętego nie ma chrześcijaństwa wczesnonowożytnego, a więc takiego, dla którego apologetyka i dogmatyka jest wyzwaniem znacznie większym od proklamacji. Wobec tego te granice, które bylibyśmy jeszcze skłonni akceptować, powiedzmy, na samym początku XVI wieku, granice między apologetyką, dogmatyką i proklamacją, w ciągu XVI stulecia zaczynają się coraz bardziej zacierać. Wraz z nimi zmienia się zupełnie sposób myślenia o chrześcijaństwie, formy tożsamości chrześcijańskiej multiplikują się na taką skalę, że już samo bycie prawdziwym chrześcijaninem staje się przedmiotem nad wyraz intensywnego sporu. W rezultacie tego zmianie ulega także myślenie o teologii, która staje się na ogół czujną protokolantką tych epokowych transformacji.

Zwracając uwagę na proklamacyjne implikacje ówczesnych tłumaczeń nie miałem na myśli wyłącznie tych prób, które podejmował na przykład Erazm ze swoją koncepcją prawdziwego chrześcijaństwa jako „filozofii Chrystusowej” albo Luter, który w swoim przekładzie Biblii chciał posługiwać się niemczyzną, którą mówi się w domach, na ulicach czy targowiskach. Nade wszystko chodzi mi tutaj o ówczesne ciążenie ku proklamacji jako istocie teologii chrześcijańskiej, o kerygmatyczny wymiar samego chrześcijaństwa. Trzeba podkreślić, że były to próby wciąż nieśmiałe, rozpoczynające się około drugiej i trzeciej dekady XVI wieku, a następnie spowolnione albo nawet zatrzymane pod naporem konfesjonalizacji, która instytucjonalną inicjatywę zwierzchnictwa programowo przedkładała nad kerygmatyczną otwartość chrześcijan. Tak długo bowiem proklamacja w pełni nie doszła nomen omen do głosu, jak z jej słownika nie zostało usunięte lub chociaż zbagatelizowane pojęcie heretyka. To nie tylko obelga, nomen criminis, ale nade wszystko nomen separatum, nazwa wykluczenia poza określone uniwersum religijne i konstytuującą je naukę. Epokową przeszkodą dla proklamacji jako nieśmiało nadchodzącej istoty teologii i kerygmatycznej (nie 
zaś wyznaniowej) natury chrześcijaństwa jest właśnie konstytutywne dla pojęcia herezji wytyczanie granic doktryny i definiowanie jej prawowierności, obrona i utrzymywanie jej w granicach wyznaczonych przez te wspólnoty interpretacyjne, które począwszy od XVI stulecia określano mianem konfesji. Przywoływany tutaj wielokrotnie Stanisław Hozjusz to przykład kogoś, kto przyczynił się do wyhamowania tego proklamacyjnego zwrotu teologii chrześcijańskiej, zainicjowanego między innymi przez Erazma, a kontynuowanego przez rzeczników chrześcijaństwa bezwyznaniowego, którym - co znamienne dla tej tendencji epoki konfesjonalizacji - wielkie denominacje zupełnie odmawiały prawa do bycia chrześcijanami. Kto czytał Confessio catholicae fidei christiana Hozjusza, ten chyba dobrze wie, jakie miejsce wśród priorytetów teologii zajmuje tam proklamacja, jak dalece została ona zmarginalizowana kosztem obrony tego, co uznane za normatywne, kosztem dogmatyzowania chrześcijaństwa, czyli tworzenia kolejnych konstrukcji normatywności o uniwersalnym zastosowaniu, a przynajmniej o takich właśnie kolonizacyjnych aspiracjach ${ }^{16}$. Nie chcę demonizować i w ten sposób wyróżniać Hozjusza, podaję tylko jeden, ufam, że miarodajny przykład. To samo powiedzieć można przecież o większości ówczesnych konfesji, jeśli nie o każdej z nich. Z definicji spełniały one dogmatyczno-apologetyczne funkcje, gdzie granica jako kres akceptowalności znaczyła w praktyce znacznie więcej niż proklamacyjna konieczność zniesienia przyjętej wykładni Pisma w faktycznym byciu. To znamienne, że problemem, wyzwaniem dla teologii staje się wytyczenie, zachowywanie i kontrolowanie takiej granicy. W swojej Confessio Hozjusz wręcz poświęca osobny rozdział precyzyjnym sposobom odróżniania katolika od heretyka. Kryterium takiej różnicy, a więc i granica tego, co akceptowalne w ramach określonego uniwersum religijnego, ma wyłącznie doktrynalny charakter, bo zawiera się w określonych postanowieniach kościelnego magisterium. To ostatnie natomiast sprowadza się do stosowania hermeneutycznych kanonów, jak „właściwie” interpretować Biblię i jak odróżnić interpretację adekwatną od tzw. nadinterpretacji, czyli herezji.

16 Zob.S.Hozjusz, Chrześcijańskie wyznanie wiary katolickiej, przeł.J. Wojtkowski, Olsztyn 1999. 
By dostrzec w kontrastywnie wyostrzonej postaci skalę tej niezrealizowanej u progu nowożytności możliwości, posłużę się tu stanowiskiem kilku teologów i hermeneutów protestanckich XX wieku. Rudolf Bultmann, Gerhard Ebeling, Paul Ricoeur oraz Gerhard O. Forde w tym między innymi pozostają zgodni, że ostatecznym przeznaczeniem teologii chrześcijańskiej jest proklamacja i nic więcej. To zmienia w zasadzie wszystko. Wyzwaniem dla biblistyki nie jest już bowiem gabinetowe rozumienie języka biblijnego, a więc posiadanie kompetencji filologicznych, ani dostarczanie normatywnych interpretacji, czyli dysponowanie władzą zwierzchnią, ale rozumienie siebie w języku objawienia, kształtowanie własnej podmiotowości w zwierciadle biblijnym. Lektura Pisma w języku, który odpowiada naszym doświadczeniom rzeczywistości (czyż tłumaczom z XVI i XVII wieku nie chodziło o odnalezienie właśnie takiej mowy), winna ujawniać nie tylko znaczenia poszczególnych miejsc, ale nade wszystko samo słowo Boże, które bez przerwy pozostaje tzw. „zdarzeniem słownym”. Co za tym idzie, podstawowym celem takiej lektury nie jest dogmatyczna deszyfracja komunikatów, ale umożliwienie uczestnictwa w takim zdarzeniu, nawiązanie tzw. „egzystencjalnego spotkania” ze słowem. Wówczas kerygmatyczna istota chrześcijaństwa zyskuje swoje uzasadnienie w naturze słowa Bożego, które nie tyle komunikuje albo przekazuje treści, co otwiera samego człowieka na określone możliwości bycia. Ten sposób myślenia o Biblii zaczyna się w XVI wieku wraz z dostrzeżeniem potrzeby przekładu i przeniesienia Pisma Świętego na nowe obszary. Pismo Święte tłumaczone jest przede wszystkim ze względu na głoszenie Słowa Bożego, żeby ono wreszcie dotarło, by stało się konstytutywną częścią konkretnego doświadczenia. W proklamacji chodzi nie tyle o wyjaśnianie i utrwalanie znaczeń, a więc nie tyle o udzielanie odpowiedzi na pytanie, ale o odpowiedź na wyzwanie, czyli o działanie, o uwolnienie performatywnej sprawczości słowa Bożego. Oto w dużym skrócie zwieńczenie tej historii, której początek sięga kryzysu reformacyjnego. Erazm oczekuje bowiem, by Pismo Święte stało się jak słońce - dostępne wszystkim: niech nawet Turcy i kobiety czytają Biblię (to w drugiej dekadzie XVI wieku brzmiało znacznie mocniej niż dzisiaj), skoro o tożsamości chrześcijańskiej decyduje jedynie naśladowanie 
Chrystusa lub, by ująć to nieco inaczej, przeglądanie się we własnym przyszłym zwierciadle, którym jest Chrystus. Tłumaczenia biblijne albo inicjują ten proklamacyjny zwrot teologii, albo są jego beneficjentami. Konfesjonalizacja jednak zupełnie ten zwrot ujarzmiła, a w najlepszym razie na długi czas uśpiła.

Transkrypcja: Aleksander Glich Redakcja: Alicja Bielak, Tadeusz Rubik

Dr Alicja Bielak - wykładowca na Wydziale Artes Liberales Uniwersytetu Warszawskiego oraz pracownik konsorcjum RETOPEA z siedzibą w Katolickim Uniwersytecie Lowańskim. Do jej zainteresowań badawczych należy szeroko pojęta historia intelektualna doby nowożytnej ze szczególnym uwzględnieniem emblematyki, medytacji, nihilizmu oraz radykalnej reformacji.

Dr Jakub Koryl - wykładowca na Wydziale Polonistyki Uniwersytetu Jagiellońskiego, dokumentalista w Centrum Badawczym Bibliografii Polskiej Estreicherów. Interesuje się historią intelektualną wczesnej nowożytności, egzegezą biblijną, hermeneutyką oraz teologią protestancką i filozofią niemiecką XX wieku. Jest laureatem Nagrody Prezesa Rady Ministrów za rozprawę doktorską Erazmianizm w polskiej kulturze literackiej XVI wieku.

Dr hab. Maciej Ptaszyński - pracownik w Instytucie Historycznym Uniwersytetu Warszawskiego, wykładał również na Uniwersytecie Jana Gutenberga w Moguncji. Do jego zainteresowań naukowych należą historia duchowieństwa luterańskiego oraz dzieje reformacji i erazmianizmu. Opublikował m.in. rozprawę Reformacja w Polsce a dziedzictwo Erazma z Rotterdamu, uhonorowaną Nagrodą Ministra Nauki i Szkolnictwa Wyższego za najlepszą książkę akademicką na Poznańskich Targach Książki w roku 2019. 